\title{
SOIL FERTILITY EVALUATION OF COFFEE (Coffea spp.) PRODUCTION SYSTEMS AND MANAGEMENT RECOMMENDATIONS FOR THE BARAHONA PROVINCE, DOMINICAN REPUBLIC
}

\author{
P.A. Núñez ${ }^{1 *}$, A. Pimentel ${ }^{1}$, I. Almonte ${ }^{1}$, D. Sotomayor-Ramírez ${ }^{2}$, N. Martínez ${ }^{3}$, \\ A. Pérez ${ }^{1}$, and C.M. Céspedes ${ }^{1}$ \\ ${ }^{1}$ Investigadores Instituto Dominicano de Investigaciones Agropecuarias y Forestales \\ (IDIAF), Avenida Imbert \# 5, Las Carolinas, La Vega, República Dominicana. \\ ${ }^{2}$ Catedrático del Departamento de Ciencias Agroambientales, Colegio de Ciencias \\ Agrícolas, Universidad de Puerto Rico, Recinto Mayagüez, Puerto Rico. ${ }^{3}$ Magister \\ en Ecología y Medio Ambiente, Universidad Pedro Henríquez Ureña, Santo \\ Domingo, República Dominicana.*Corresponding author: pnunez@idiaf.gov.do
}

\begin{abstract}
Reported yields in most coffee farms of the Barahona province in the Dominican Republic are relatively low $\left(<290 \mathrm{~kg} \mathrm{ha}^{-1}\right.$ parchment coffee). In general, coffee producers do not use diagnostic techniques such as soil testing. This fact prevents them from identifying the limiting factors (especially nutrients), complicates the work of coffee cultural management practices, and potentially reduces productivity and coffee quality. This study was designed to diagnose the fertility level of soils in coffee farms in the area of Barahona in 96 farms within an area of 637 hectares and design a nutrient management strategy. Soils from each farm were sampled and analyzed for soil fertility parameters. A survey was provided to farmers that permitted the collection of information regarding yields, management practices, and landscape features. Soils in the area were predominantly clayey. Soil pH varied between 4.61 and 7.69 and soil organic matter ranged between 3.29 and 10.9\%. Exchangeable potassium levels were classified as deficient in all areas. The clustering of results identified two main components, which accounted for $76 \%$ of the variability of the data and the grouping into five communities by similarity of features. The results show that soil testing of this coffee coffee-growing region can be used as a tool to diagnose the soil fertility status and guide them in implementing management and fertilization recommendations.
\end{abstract}

Keywords: soil fertility, yield coffee, fertility diagnostic, Dominican Republic.

\section{INTRODUCTION}

The production of coffee (Coffea spp.) has of great economic and social importance at local, regional and global levels. In the Dominican Republic, coffee is second most important agricultural product for export, after cocoa. Bean exports from Dominican Republic have stabilized in the last 4 years (2006-2009) with an average of 122,000 quintals (1 quintal $=45.5 \mathrm{~kg}$ ) of market coffee per 
year, after averaging only 61,000 quintals in the years 2004 and 2005. Said amount represents an increase of about $100 \%$ in the volume of these exports. For this same period, the annual value of bean exports has increased from US\$ 6.8 to US\$ 17 million, which represents an increase of $150 \%$ in export value (CODOCAFE, 2010). In the 2009, national coffee production recorded an increase of $6.65 \%$ compared to 2008, while the export value of 137,580 quintals of green coffee increased by $32.71 \%$ over that in 2009, for a value of US\$ 20.9 million. The estimated production of parchment coffee is between 600,000 and 700,000 quintals (27,273 to 31,818 metric tons). The Dominican Republic has a coffee production area of 132,500 ha occupied by 50,000 farmers (CODOCAFE, 2002).

A sustainable system of coffee production should prevent soil erosion and contribute to the preservation of forests and their associated habitat (Martinez, 2010). This system should also produce environmental benefits, such as conservation of flora and fauna (provides protection and shelter for native and migratory species of birds), increase the scenic value of the field, and improve air quality (Hergoualc'h et al., 2008). Coffee is a crop that is produced under a variety of growing conditions, and is widely cultivated in tropical climates (CENICAFE, 1999) with similar conditions to those in the Dominican Republic (Vicente-Chandler et al., 1968). The coffee production zone in the Dominican Republic has average annual temperatures between 17 and $30^{\circ} \mathrm{C}$, rainfall ranging between 1000 and 2400 $\mathrm{mm}$ and altitudes between 200 and 1400 m.a.s.l. Although there are ecologically suitable for coffee production, the yields reported in the majority of farms are relatively low $(<290 \mathrm{~kg}$ parchment coffee $\left.\mathrm{ha}^{-1}\right)$. Soil is one of the most important factors related to the productivity of coffee (Almonte, 2008). Avelino et al. (2002) reported that the acidity and soil texture influence the quality of the grain coffee. Escarramán et al. (2008) reported that the planting altitude and variety are the factors that have the greatest influence on the granulometry and sensory characteristics of coffee.

In the Barahona Province of the Dominican Republic, coffee is planted mainly under shade conditions. According (Almonte, 2008), most coffee soil from Barahona province belong to the order Inceptisols and Entisols. The soils vary from moderate to strongly acidic. However, this information is not conclusive and varies according to the management. Farmers in the area generally lack specific knowledge about the properties associated with the fertility of farm soils. The lack of quantitative knowledge related to crop limiting factors, prevents farmers from taking proper corrective actions; hinders cultural cropping practices, and reduces coffee yield and quality. Proper diagnosis and sustainable fertilizer recommendations cannot be made without recent information on the fertility characteristics of soils. This research was conducted with the goal of diagnosing the nutrient status and other soil fertility limiting factors, and to refine management options for these agroforestry systems in the Barahona Province.

\section{MATERIALS AND METHODS}

\section{Experimental site and description area}

The Barahona Province has an extension of $1,639 \mathrm{~km}^{2}$. It is located between latitudes $18^{\circ} 40^{\prime}$ and $18^{\circ} 12^{\prime} \mathrm{N}$ and longitudes $71^{\circ} 17^{\prime}$ and $71^{\circ} 21^{\prime} \quad \mathrm{W}$, southwest of the Dominican Republic. The area has an altitude between 700 and 
1200 m.a.s.l., has a temperature annual range of 17 and $221^{\circ} \mathrm{C}$ with an annual average of $26^{\circ} \mathrm{C}^{1}$. The annual rainfall varies between 655 and $2296 \mathrm{~mm}$ (Pérez et al., 2002). The coffee cultivated area in the Barahona Province is 11,082 ha with about 3,565 participating farmers (CODOCAFE, 2002). Most of the area (98.6\% or $30,710 \mathrm{ha}$ ) is in arabica cofee (C. arabica), whith the remainder (1790 ha) is planted to robusta coffee ( $C$. canephora).

\section{Farm survey and soil sampling}

The fifteen coffee production areas of the Provice were identified from which 96 farms were selected. The farms were identified based on the 2001 National Coffee Census (CODOCAFE, 2001). The sample size was computed using the software InfoStat (2008), with an error of $10 \%$, considering the total number of coffee farms (3,565 farms), in an area of 11,082 ha. Specific location of each farm was made using using topographic sheets for the area. All farm visits were made from April to July 2009.

The distribution of cases by location was based on proportion of farms and area occupied by location: Las Guázaras (7), Santa Helena (9), Bahoruco (6), Las Ciénaga (12), Polo (3), Bretón (10), Monteada Nueva (1), La Lanza (7), Los Charquitos (8), Platón (1), Leonardo (7), Los Patos (7), María Teresa (5), Chene (7) and El Pino (6). Each farm was georeferenced with GPS model Garmin GPS 76 (Garmin International Inc., Olathe, KS). A survey was prepared and personally supplied to each farmer in order to characterize current yields, agronomic practices and other related information, for example: weed control, pest management practices, soil

${ }^{1}$ http://es.wikipedia.org/wiki/Barahona_Rep\%C3 \%BAblica Dominicana) conservation practices, extent of shadetree pruning, coffee tree pruning and fertilization or manure management practices.

Soils were sampled to a depth of 30 $\mathrm{cm}$ with bore or cutting blade. A composite sample from each farm was gatherd by taking six subsamples from each of the three main geomorphologic positions (shulder, backslope, foot-toe slope) at the farm. Two subsamples were gathered from each geomorphologic position). All leaves and other surface debris were removed by hand. The six sub-samples were homogenized to obtain a composite sample of $2 \mathrm{~kg}$. Samples were placed in previously identified plastic bags and sent to the laboratory for analisis within two weeks.

\section{Soil characteristics}

Soil samples were air-dried and sieved to pass a 2-mm mesh sieve. Soils were analyzed for soil fertility characteristics following methodology outlined in Page et al. (1982).

The $\mathrm{pH}$ was determined in a ratio $1: 2$ (soil:water) using a potentiometer. The organic matter (OM) was measured by the Walkey and Black method (potassium dichromate oxidation). The electrical conductivity was determined on the supernatant obtained from a 1:2 (soil: water) suspension using a conductivity bridge. The total nitrogen (TN) was measured using the Kjeldahl method. Available $\mathrm{P}$ was extracted using the Mehlich III extractant followed by quantification in a UV-Vis spectrophotometer. The exchangeable bases were measured by the extraction with $\mathrm{NH}_{4} \mathrm{OAC}$ followed by quantification using atomic absorption. Exchangeable acidity was extracted with $1 \mathrm{M} \mathrm{KCl}$, followed by the quantification of $\mathrm{Al}$ and $\mathrm{H}$ by titration. The micronutrients iron $(\mathrm{Fe})$, copper $(\mathrm{Cu})$, manganese $(\mathrm{Mn})$ and 
zinc $(\mathrm{Zn})$ were determined by the method of digestion with nitric-perchloric acid by followed by quantification by atomic absorption.

We calculated the effective cation exchange capacity (ECEC) based on the sum of the bases and exchangeable acidity. Aditional relations such as $\mathrm{Ca} / \mathrm{Mg}, \quad \mathrm{Mg} / \mathrm{K}, \quad \mathrm{Ca}+\mathrm{Mg} / \mathrm{K}$, sodium saturation percentage (SSP) and aluminum saturation percentage (ASP) were calculated. The texture was measured in the laboratory using a hydrometer Bouyucos (Page et al., 1982).

All tests were performed according to the standard protocols of the CENTAIDIAF Soil Test Laboratory. Each sample was tested the color (wet) with the Munsell color chart.

\section{Statistical analysis}

The data were analyzed using descriptive statistics, using the InfoStat software (version 2008). Multivariate analysis was applied to the data: principal component analysis (PCA) and cluster analysis, with clustering by Euclidean distance.

\section{RESULTS AND DISCUSSION}

\section{Overview of the coffee farms}

Most coffee production farms in the Barahona province are small, as 64\% had an area less than 5 ha and $56 \%$ of were between 2.1 and 5.0 ha. The median farm area was 3.75 ha. The largest farms were found in Chene and Las Cienagas locations with a mean area of 56 ha and the smallest were found in Polo and Los Charquitos with a mean of 0.94 ha (Table 1). This information coincides with that reported by Nuñez and Cuevas (2004) in coffee plantations in the provinces of Monseñor Nouel and La Vega. As the farms were small, the farmers may lack the resources to hire and/or perform diagnostic techniques for soil nutrient status and plant.

The coffee farms evaluated were in an altitude range of 309 to 1279 m.a.s.l. Most farms (64\%) were within ranges considered optimal for coffee production, which is between 700 and 1,000 m.a.s.l (Almonte, 2008; Almonte et al., 2010). About $17 \%$ of the farms were located at altitudes above 1,000 m.a.s.l. and the remaining $19 \%$ were at or below 700 m.a.s.l. The average soil slope range was between 0.5 and 20\%. However, on occasion, some slopes of over $50 \%$ or more were identified, and predominated in Guindadero and El Membrillo in Bahoruco locations.

Most of the farms were planted to Caturra and Typica variety. The highest percentage (69\%) of farms had Typica coffee and a smaller percentage (31\%) had Caturra. The highest coffee parchment yields were reported in Los Patos (501 kg ha ${ }^{-1}$ ), Monteada Nueva (464 kg ha ${ }^{-1}$ ) and Maria Teresa (315 kg $\mathrm{ha}^{-1}$ ). These yields are slightly higher than those reported nationally for parchment coffee of $290 \mathrm{~kg} \mathrm{ha}^{-1}$. The reported yields in the remaining locations were lower than the national average $\left(<200 \mathrm{~kg} \mathrm{ha}^{-1}\right.$ parchment coffee). A possible reason for the low yields is that farmers do not fertilize adequately, there is no structured agronomic management program (including pest management, pruning, replanting), lack of manpower, and reduction in international prices coffee, all of which discourage the farmers to use available technology (Table 1).

\section{Coffee plantation management and soil description}

The coffee farmers that were surveyed did not use chemical fertilizers. About $16 \%$ of farms carried out some type of practice 
Table 1. Ranges of elevation, slope, yields and crop area $(n=96)$.

\begin{tabular}{lcccc}
\hline Locations & Altitude & Slope & Yield*** & $\begin{array}{c}\text { Cultivated } \\
\text { area** }\end{array}$ \\
\hline La Guázara & m.a.s.l. & $\%$ & $\mathrm{~kg} \mathrm{ha}^{-1}$ & ha \\
Santa Elena & $641-1040$ & $0-40$ & $116-291$ & $1.8-12.5$ \\
Bahoruco & $674-837$ & $0-45$ & $58-175$ & $2.0-3.1$ \\
La Cienaga & $493-714$ & $0-50$ & $59-255$ & $2.2-6.3$ \\
Polo & $448-855$ & $0-30$ & $80-400$ & $1.9-56.3$ \\
Bretón & $703-721$ & $0-5$ & $112-416$ & $1.0-4.4$ \\
Monteada & $717-1063$ & $0-30$ & $48-280$ & $2.5-12.5$ \\
Nueva* & $1161-1161$ & $0-10$ & 464 & 3.25 \\
La Lanza & $891-1139$ & $0-20$ & $96-400$ & $2.5-25.0$ \\
Los Charquitos & $1193-1279$ & $0-40$ & $64-176$ & $1.9-4.4$ \\
Platón* & 309 & 10 & 120 & 3.16 \\
Leonardo & $563-893$ & $0-30$ & $96-320$ & $3.1-9.4$ \\
Los Patos & $710-937$ & $0-30$ & $48-2000$ & $1.9-25.0$ \\
María Teresa & $578-819$ & $0-35$ & $160-560$ & $1.3-9.4$ \\
Chene & $807-1035$ & $0-25$ & $96-400$ & $1.3-52.8$ \\
El Pino & $948-995$ & $0-25$ & $80-336$ & $2.5-9.4$ \\
\hline
\end{tabular}

* Only one sample was taken so it appears a single value and not the range.

** $69 \%$ of the area is dedicated to coffee Typica (8-80 years) and 31\% of coffee Caturra (1-40 years).

*** None of the producers made chemical fertilizers, organic fertilizer made only 7 (7.29\%).

associated with the use of organic amendments in solid or liquid form in the form of plant residues or animal manures. Therefore, the vast majority of farmers depend on the capacity of the soil and recycling of plant materials to supply nutrients to the crop. About $78 \%$ of farms do not use any soil conservation practice.

All farms had some type of shade in the form of fruit trees or evergreen secondary forest. The shading extent was not quantified. The majority of farmers
(92\%) carry out some form shading management. In all farms, inga (Inga vera), was the dominant shade species and to a lesser extent poppy (Erythina poeppigiana), cedar (Cedrela odorata), avocado (Persea americana), several species of citrus (Citrus spp.), royal palm (Roystonea hispaniolana, and fig tree (Ricinus communis). Most coffee plantations are inter-cropped with banana (Musa AAA), and is used to supplement farmer's income when coffee is not being 
harvested. Other minor inter-cropped crops were yam (Xantosoma spp.), squash (Sechium edule), cassava (Manihot esculenta) and plantain (Musa AAB).

All farmers control weeds manually or with selective herbicide. All farmers control the coffee borer (Hypothenemus hampei) using recommendations made by the Dominican Coffee Council (CODOCAFE), which are a combination of cultural practices and the use of traps. The other pests or diseases of the coffee are not considered economically important, and are not managed.

Soil texture varied among farms. About $52 \%$ of soils were predominantly clayey, $21 \%$ were silt-loam, $16 \%$ were clay-loam, $10.4 \%$ were loamy, and $1 \%$ of the farms were sandy-loam (Table 2). The representative colors of the soils in the Barahona province are: red (2.5YR4/6, 2.5YR4/8, 7.5R4/6), yellowish brown (10YR5/6), yellowish red (5YR4/6, 5YR5/6), brown (7.5YR4/2, 7.5YR4/3, 7.5YR4/4), reddish brown (2.5YR4/4), dark brown (10YR3/3, 7.5YR5/6, 10YR3/3), dark yellowish brown (10YR4/4), dark reddish brown (2.5YR3/3), brownish yellow (10YR6/6), pale yellow (2.5Y8/3), strong brown (7.5YR5/6) and reddish yellow (7.5YR6/6). These colors vary with the locations and the soil depth (data not shown).

Table 2. Texture and percentage occurrence in the province Barahona ( $n=96)$.

\begin{tabular}{lcccccccc}
\hline Provinces & \multicolumn{6}{c}{ Number and percentage of coffee farms/ texture type } \\
\cline { 2 - 7 } & Clay & Loamy & CL & SL & SaL & ClL & FCL & Total \\
\hline Barahona & 50 & 10 & 15 & 20 & 1 & 0 & 0 & 96 \\
& $(52.1)$ & $(10.4)$ & $(15.6)$ & $(20.8)$ & $(1.0)$ & $(0.0)$ & $(0.0)$ & $(100.0)$ \\
\hline
\end{tabular}

Values in parentheses (\%); Franco clay loam (FCL); Clay loam (CL); Silt loam (SL); Sandy loam $(\mathrm{SaL})$; Clayey loam (ClL).

Soil reaction was acid in six locations (Monteada Nueva, La Cienega, Los Patos, Platón, La Lanza and Bahoruco), but there was a wide range of soil reaction that ranged from with mean soil $\mathrm{pH}$ of 6.14 (Table 3). The electrical conductivity (EC) ranged from 0.13 to $0.92 \mathrm{dS} \mathrm{m}^{-1}$. Soil organic matter ranged between 3.0 and $10.8 \%$ with an average of $7.4 \%$. The mean total $\mathrm{N}$ in all soils was $0.53 \%$. The mean available $\mathrm{P}$ was $14.3 \mathrm{mg} \mathrm{kg} \mathrm{mg}^{-1}$ and exchangeable potassium $(\mathrm{K})$ was 0.27 $\mathrm{cmol}(+) \mathrm{kg}^{-1}$ in the range of 0.12 to 0.45 $\left.\operatorname{cmol}(+) \mathrm{kg}^{-1}\right)$. The mean content of extractable iron (Fe), zinc (Zn), magnesium $(\mathrm{Mg})$ and copper $(\mathrm{Cu})$ were 215, 4.67, 46.6, $5.99 \mathrm{mg} \mathrm{kg}^{-1}$, respectively. Soil exchangeable calcium (Ca) varied between 2.26 and 43.44 cmol(+) $\mathrm{kg}^{-1}$, and exchangeable $\mathrm{Mg}$ content ranged from 0.55 to $3.56 \mathrm{cmol}(+)$ $\mathrm{kg}^{-1}$. The effective cation exchange capacity (ECEC) ranged from 4.67 to 46.3 cmol(+) $\mathrm{kg}^{-1}$ and ratios of $\mathrm{Ca} / \mathrm{Mg}$ were between 4 and 20, very similar to the $\mathrm{Mg} / \mathrm{K}$ ratios in the range of 6 to 17$)$. The $\mathrm{Ca}+\mathrm{Mg} / \mathrm{K}$ ratios were high (27 to 194). $\mathrm{Na}$ and $\mathrm{Al}$ saturation indices were in 
Table 3. Mean values of soil chemical properties of the coffee by locations in Barahona ( $\mathrm{n}=96)$.

\begin{tabular}{|c|c|c|c|c|c|c|c|c|c|c|c|c|c|c|c|c|c|c|c|c|}
\hline \multirow[b]{2}{*}{ Locations } & \multirow{2}{*}{$\begin{array}{c}\text { pH 1:2 } \\
\text { water }\end{array}$} & \multirow{2}{*}{$\begin{array}{c}\text { EC } \\
\mathrm{dS}^{-1}\end{array}$} & \multicolumn{6}{|c|}{ cmol(+) $\mathrm{kg}^{-1}$} & \multirow[b]{2}{*}{$\mathrm{Ca} / \mathrm{Mg}$} & \multirow[b]{2}{*}{$\mathbf{M g} / \mathbf{K}$} & \multirow[b]{2}{*}{$\mathrm{Ca}+\mathrm{Mg} / \mathrm{K}$} & \multirow[b]{2}{*}{ ASP (Al) } & \multirow[b]{2}{*}{ SSP (Na) } & \multicolumn{5}{|c|}{$\mathrm{mg} \mathrm{kg}^{-1}$} & \multirow{2}{*}{$\begin{array}{c}\text { OM } \\
\%\end{array}$} & \multirow{2}{*}{$\begin{array}{l}\text { TN } \\
\%\end{array}$} \\
\hline & & & $\mathbf{C a}$ & Mg & $\mathbf{K}$ & $\mathrm{Na}$ & H, Al & ECEC & & & & & & $\mathbf{F e}$ & Mn & $\mathbf{C u}$ & Zn & $\mathbf{P}$ & & \\
\hline Monteada Nueva & 4.79 & 0.27 & 2.26 & 0.55 & 0.09 & 0.12 & 1.64 & 4.67 & 4.10 & 6.17 & 31.46 & 2.60 & 2.60 & 230.87 & 131.01 & 17.51 & 5.88 & 23.00 & 3.29 & 0.35 \\
\hline La Ciénaga & 4.61 & 0.20 & 4.67 & 1.08 & 0.20 & 0.26 & 0.48 & 6.69 & 4.11 & 5.43 & 27.85 & 9.30 & 4.94 & 768.00 & 73.60 & 6.14 & 13.34 & 40.31 & 5.99 & 0.34 \\
\hline Los Patos & 5.43 & 0.25 & 11.01 & 1.46 & 0.23 & 0.37 & 0.30 & 13.36 & 6.85 & 6.48 & 51.23 & 4.17 & 3.73 & 485.30 & 55.28 & 5.50 & 3.80 & 24.23 & 7.71 & 0.47 \\
\hline Platón & 5.06 & 0.18 & 7.64 & 1.76 & 0.21 & 0.37 & 0.41 & 10.39 & 4.35 & 8.53 & 45.65 & 3.98 & 3.57 & 182.56 & 82.69 & 3.52 & 4.82 & 11.03 & 9.70 & 0.47 \\
\hline La Lanza & 5.91 & 0.55 & 16.22 & 1.40 & 0.20 & 0.22 & 0.35 & 18.40 & 10.16 & 6.81 & 82.52 & 5.27 & 1.60 & 165.87 & 32.55 & 9.52 & 3.56 & 20.14 & 4.68 & 0.52 \\
\hline Bahoruco & 4.53 & 0.13 & 2.90 & 0.90 & 0.12 & 0.28 & 0.81 & 5.00 & 2.90 & 7.64 & 30.98 & 20.40 & 6.65 & 435.09 & 52.03 & 3.91 & 3.16 & 13.49 & 5.24 & 0.28 \\
\hline Polo & 7.93 & 0.51 & 35.39 & 3.56 & 0.21 & 0.24 & 0.00 & 39.40 & 11.17 & 17.25 & 194.44 & 0.00 & 0.61 & 10.01 & 1.20 & 1.33 & 1.11 & 15.00 & 4.84 & 0.34 \\
\hline Los Charquitos & 7.69 & 0.92 & 43.43 & 2.23 & 0.45 & 0.28 & 0.00 & 46.39 & 20.24 & 5.54 & 113.68 & 0.00 & 0.60 & 7.42 & 6.20 & 13.23 & 3.84 & 6.38 & 9.52 & 0.73 \\
\hline Chene & 6.06 & 0.43 & 26.50 & 2.70 & 0.33 & 0.42 & 0.10 & 30.05 & 10.50 & 8.20 & 84.78 & 0.57 & 1.73 & 132.60 & 92.36 & 4.66 & 8.09 & 14.41 & 10.85 & 0.70 \\
\hline El Pino & 6.48 & 0.54 & 32.17 & 2.94 & 0.39 & 0.37 & 0.00 & 35.87 & 11.50 & 7.96 & 91.66 & 0.00 & 1.14 & 41.64 & 49.67 & 2.59 & 3.68 & 4.70 & 10.24 & 0.74 \\
\hline María Teresa & 6.39 & 0.48 & 24.74 & 2.43 & 0.39 & 0.48 & 0.00 & 28.03 & 10.19 & 6.65 & 75.84 & 0.00 & 1.84 & 176.36 & 44.88 & 4.63 & 5.32 & 7.30 & 8.87 & 0.54 \\
\hline Los Leonardos & 6.61 & 0.50 & 32.07 & 3.03 & 0.27 & 0.45 & 0.08 & 35.90 & 11.91 & 12.30 & 139.03 & 0.38 & 1.62 & 291.38 & 7.15 & 5.94 & 2.80 & 12.78 & 7.02 & 0.52 \\
\hline Bretón & 7.11 & 0.83 & 35.98 & 3.04 & 0.39 & 0.28 & 0.00 & 39.69 & 13.22 & 8.21 & 109.04 & 0.00 & 1.05 & 10.48 & 7.60 & 6.17 & 2.16 & 13.80 & 6.80 & 0.68 \\
\hline Santa Elena & 6.73 & 0.62 & 40.29 & 2.34 & 0.26 & 0.27 & 0.00 & 43.17 & 16.88 & 8.71 & 157.31 & 0.00 & 1.03 & 239.24 & 28.05 & 2.75 & 3.63 & 4.60 & 7.44 & 0.63 \\
\hline La Guázara & 6.77 & 0.57 & 37.37 & 2.48 & 0.32 & 0.27 & 0.00 & 40.45 & 14.92 & 7.99 & 121.23 & 0.00 & 0.76 & 51.15 & 35.01 & 2.56 & 4.88 & 4.51 & 8.81 & 0.66 \\
\hline
\end{tabular}

EC, electrical conductivity; ECEC, effective cation exchange capacity; Ca, calcium; magnesium, Mg; K, potassium; Na, sodium; EA, exchangeable acidity; ASP, aluminum saturation percentage; SSP, sodium saturation percentage; Fe, iron; Mn, manganese; $\mathrm{Cu}$, copper; Zn, zinc; P, phosphorus; OM, organic matter; TN, total nitrogen. 
range from 0.6 to $6.65 \%$ and 0.38 to 20 $\%$, respectively. We expect that these $\mathrm{Na}$ and $\mathrm{Al}$ saturation indices are not limiting coffee production in the farms.

\section{Soil fertility diagnosis of coffee farms}

The first two principal components account for $76 \%$ of the total variance (Table 4). The first component has the higher explanatory power of the data. In this component, positive values for soil $\mathrm{pH}$, EC, exchangeable bases, ECEC, $\mathrm{Ca} / \mathrm{Mg}, \mathrm{Mg} / \mathrm{K}, \mathrm{OM}$ and total N (group 1) are observed more or less in similar proportions; other variables such as $\mathrm{Na}$ saturation percentage, $\mathrm{Al}$ saturation percentage, Fe, $\mathrm{Mn}, \mathrm{Zn}$ and $\mathrm{P}$ are grouped in opposing areas of the former group. There is a high correlation between the components and variables, which assures the representativeness of the variables. The magnitude of the values is associated with desirable and un-desirable soil characteristics. As these properties are linked to the concept of nutrient availability, high values in the variables of the first group are linked to adequate soil fertility. The second component explains $14.0 \%$ of the total variability. If this component is associated with the first, it may indicate that the soils have adequate acidity, $\mathrm{Na}$ saturation percentage, $\mathrm{Al}$ saturation percentage and $\mathrm{Cu}$ and a few have problems of acidity or salinity (Table 4).

The analysis discriminates two different site-categories as opposite positions (Figure 1). On the left figure shows, related to CP1, sites with content items associated with soil salinity and acidity levels, including Monteada Nueva, La Lanza, Bahoruco, La Cienega, Los Patos and Platón. Items associated with fertility rates differ on the right vertical axis given by $\mathrm{CP} 1$, which relate to locations such as Breton, Los Charquitos, Maria Teresa, El Pino, Santa Elena,
Chene and Las Guázaras. In the upper quadrants, with respect to $\mathrm{CP} 2$, there are areas with the highest correlation elements to this component and lower quadrants elements with negative relationship.

In the cluster analysis, the locations El Pino, Chene, Maria Teresa, Los Leonardos, Bretón, Santa Elena and Las Guázaras are grouped together (Figure 2). This differentiation is shown with a dotted vertical line drawn from a value representing $50 \%$ of the maximum average euclidean distance (DEPmax), according with Indeángelo et al. (2007). The locations Las Lanzas, Polo and Los Charquitos are grouped as sites having a soil $\mathrm{pH}$ pattern that is different than the other localities, forming the classes A, C and D, respectively. Los Patos, Platón, Monteada Nueva, La Ciénaga and Bahoruco are located in class B and are characterized as having a moderately to strongly acid soil $\mathrm{pH}$.

\section{Soil test interpretation and management recommendations}

The sites were segregated into five groups based on chemical properties: class A ( $\mathrm{La}$ Lanza), class B (Los Patos, Platon, Monteada Nueva, La Cienaga and Bahoruco), class C, (Polo), class D (Los Charquitos) and class E (El Pino, Chene, Maria Teresa, Los Leonardos, Bretón, Santa Elena and Las Guázaras).

Soils from La Lanza (class A) had near favourable $\mathrm{pH}$ and $\mathrm{OM}$, and adequate $\mathrm{Ca}$ availability. The main soil fertility constraint in these soils is low $\mathrm{K}$ and $\mathrm{Mg}$ availability as these are below suggested critical levels. Because the exchangeable Ca availability is very high in relation to $\mathrm{Mg}$ and $\mathrm{K}$ availability, as evidenced by $\mathrm{Ca} / \mathrm{Mg}$ and $\mathrm{Ca}+\mathrm{Mg} / \mathrm{K}$ ratios. The soils may benefit from the addition of fertilizer containing moderate $\mathrm{Mg}$ and $\mathrm{K}$ concentrations. The soils had adequate $\mathrm{P}$ 
Table 4. Eigenvalues and proportion of explained variance calculated from the correlation matrix.

\begin{tabular}{lccc}
\hline & & \multicolumn{2}{c}{ Proportion of explained variance } \\
\cline { 2 - 4 } Components $(\lambda)$ & Eigenvalue & Absolute & Cumulative \\
\hline $\mathbf{1}$ & & 0.62 & 0.62 \\
$\mathbf{2}$ & 12.33 & 0.14 & 0.76 \\
$\mathbf{3}$ & 2.82 & 0.08 & 0.84 \\
$\mathbf{4}$ & 1.68 & 0.06 & 0.90 \\
$\mathbf{5}$ & 1.23 & 0.04 & 0.94 \\
$\mathbf{6}$ & 0.73 & 0.03 & 0.96 \\
$\mathbf{7}$ & 0.51 & 0.01 & 0.98 \\
$\mathbf{8}$ & 0.27 & 0.01 & 0.99 \\
$\mathbf{9}$ & 0.18 & 0.01 & 0.99 \\
$\mathbf{1 0}$ & 0.12 & $4.7 \mathrm{E}-03$ & 1.00 \\
$\mathbf{1 1}$ & 0.09 & $1.3 \mathrm{E}-03$ & 1.00 \\
$\mathbf{1 2}$ & 0.03 & $4.7 \mathrm{E}-04$ & 1.00 \\
$\mathbf{1 3}$ & 0.01 & $3.5 \mathrm{E}-04$ & 1.00 \\
$\mathbf{1 4}$ & 0.01 & 0.00 & 1.00 \\
$\mathbf{1 5}$ & 0.00 & 0.00 & 1.00 \\
$\mathbf{1 6}$ & 0.00 & 0.00 & 1.00 \\
$\mathbf{1 7}$ & 0.00 & 0.00 & 1.00 \\
$\mathbf{1 8}$ & 0.00 & 0.00 & 1.00 \\
$\mathbf{1 9}$ & 0.00 & 0.00 & 1.00 \\
$\mathbf{2 0}$ & 0.00 & 0.00 & 1.00 \\
$\mathbf{2 1}$ & 0.00 & 0.00 & 1.00 \\
\hline
\end{tabular}

and micronutrient availability, thus supplementation with these may not be needed.

Soils from class $\mathrm{B}$, were generally acid, with adequate soil $\mathrm{OM}$ and total $\mathrm{N}$ contents. Coffee orchards in soils from Monteada Nueva, La Cienaga, and Los Patos may not need repeated $P$ applications, yet $\mathrm{P}$ deficiency may be encountered in soils from Platón and Bahoruco. These soils are adequately balanced in terms of exchangeable basic cations, but may need to be supplemented with $\mathrm{K}$ and $\mathrm{Mg}$. Monteada Nueva, La Cienaga and Bahoruco locations have low soil $\mathrm{pH}$ with values of $4.79,4.51$ and 4.53, respectively, and is in accord with observations by Almonte (2008), for some 


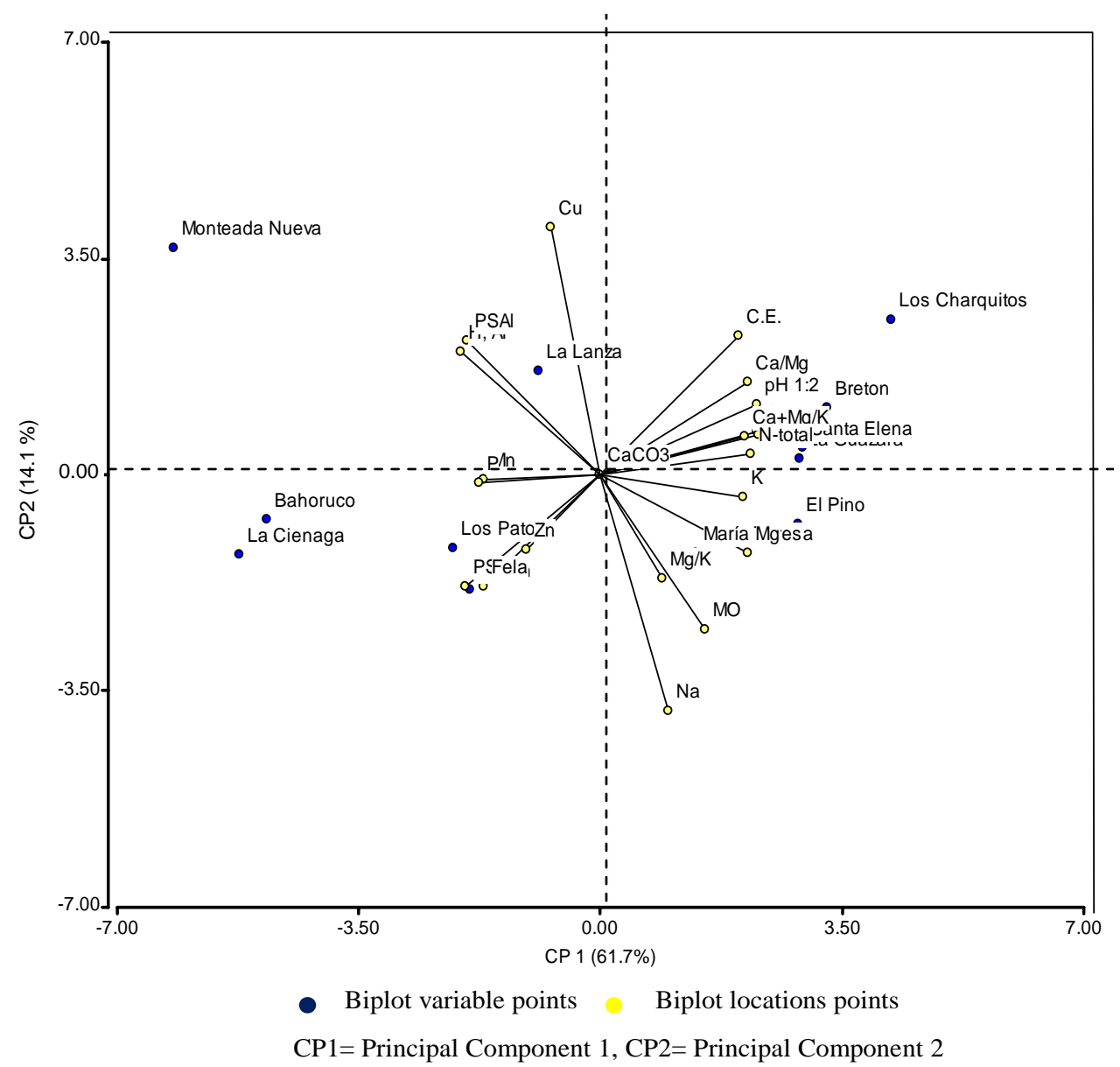

Figure 1. Distribution of variables in relation to the main components.

coffee production of soils of Barahona. These soils may require moderate lime (2 - 3 ton/ha) applications on a yearly basis. The soils of the above-mentioned locations are continually subjected to intensive processes of weathering due to steep slopes and rainfall greater than 2000 $\mathrm{mm}$. Thus special soil conservation practices need to be included in future plantings and/or coffee tree replacement programs.
Soils from Polo and Los Charquitos localities were grouped together as a class C and D, respectively. These groups had similar soil fertility characteristics, yet differed in the sense that Los Charquitos had higher soil OM and total $\mathrm{N}$ contents. Soil test $\mathrm{P}$ was in the medium category. The main soil fertility constraint in these soils appeared to be the high soil $\mathrm{pH}$ which may influence micronutrient availability. In fact these two groups of 


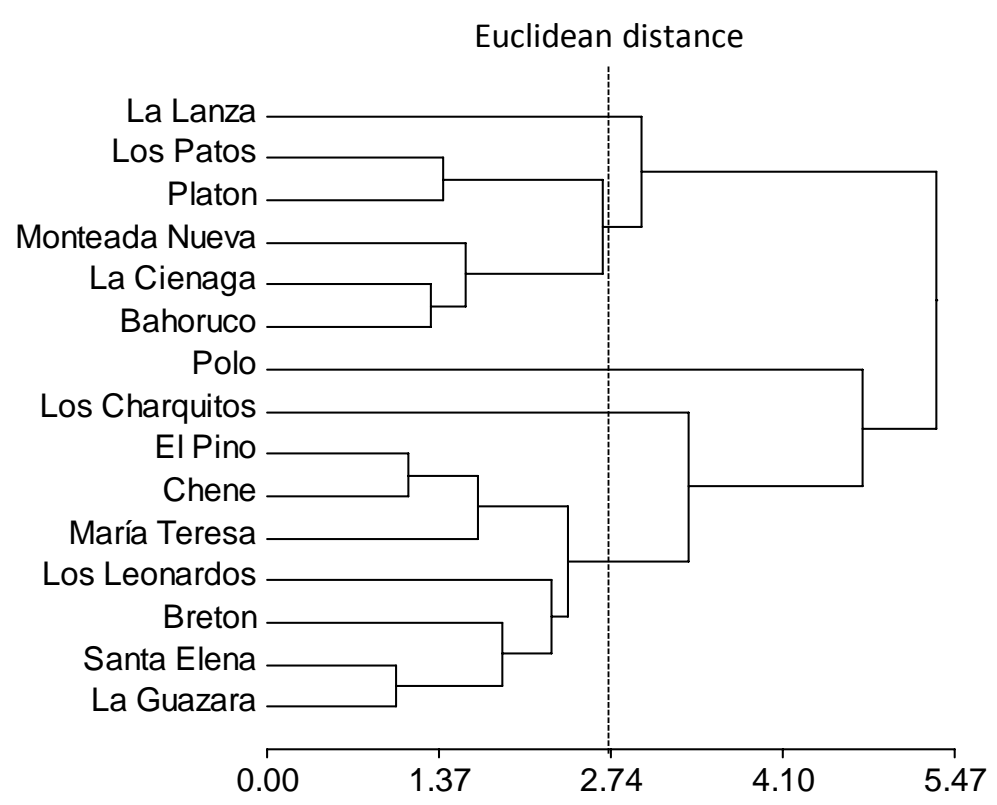

Figure 2. Distribution of the coffee communities of Barahona in relation to the groups formed by cluster analysis.

soils were the ones (along with Breton) that had low soil Fe, Mn, and $\mathrm{Zn}$ availability. Although, exchangeable $\mathrm{Ca}$ was high, $\mathrm{Mg}$ and $\mathrm{K}$ were at or above sufficiency levels in Los Charquitos, so that $\mathrm{Mg}$ and $\mathrm{K}$ are not expected to be limiting crop production. Soils from Polo may need supplementation with $K$. Fertilizer recommendations for these groups of soils should include formulations having moderate $\mathrm{P}, \mathrm{K}$, and $\mathrm{Mg}$ concentrations, and should contain special blends of micronutrients. Nutrient management in these soils should consider sources that have the potential to increase soil acidity such as organic residue application, fresh manures, and ammonium-based fertilizers.

El Pino, Chene, Maria Teresa, Los Leonardos, Breton, Santa Elena and La Guázara localities are grouped together as class E. These soils had $\mathrm{pH}$ values near the upper limit of the desirable range (mean of 6.59). Breton locations soils are the exception having a mean soil pH 7.11. In soils of this class, exchangeable $\mathrm{Ca}$ and $\mathrm{Ca} / \mathrm{Mg}$ ratios are outside the upper limit of the target range ( $>5$ and 2-10, respectively), so there may be an antagonistic effect between $\mathrm{Ca}$ and $\mathrm{Mg}$, which could be limiting $\mathrm{Mg}$ utilization. The application of $\mathrm{Mg}$ should be considered in these soils either as individual fertilizer $\mathrm{Mg}$ sources or with complete formulations. The soils from all locations had favorable soil OM content and total $\mathrm{N}$ content. Coffe growing in all locations is expected to respond to $\mathrm{P}$ application originating from fertilizer or organic residue sources. Soils in these locations should not be limited, fertilizer application should not contain or contain minimum amounts of $\mathrm{Ca}$, and may benefit from having moderate $\mathrm{Mg}$ and $\mathrm{K}$ concentrations. 
The main constraints to coffee production in the Barahona province are low soil $\mathrm{pH}$ and $\mathrm{N}$ availability. Soils with $\mathrm{pH}$ below 5.5 should be limed to reduce the potential of $\mathrm{Mn}$ and $\mathrm{Al}$ toxicicity, improve base saturation, and ECEC. The application of lime can be used to provide both $\mathrm{Ca}$ and improve soil $\mathrm{pH}$ in acid soils. In areas were soil reaction does not need to be correcterd but Ca supplementation is needed, gypsum $\left(\mathrm{CaSO}_{4} \bullet \mathrm{xH}_{2} \mathrm{O}\right)$ can be used. Coffee cultivated soils in the province of Barahona are not considered saline, so it is expected that coffee yields are not influenced by this condition (Montico, 2006).

Most of the areas sampled had relatively high accumulation of plant material as mulch on the soil surface. As the material decomposes it becomes part of the soil OM, and most of the soils from all locations had high soil OM contents. In-spite of this fact, it is not expcted for the organic matter to supply sufficient nutrients (especially $\mathrm{N}$ ) to sustain high yields, due to the lack of synchronization in $\mathrm{N}$ mineralization and plant uptake, and the large amounts of $\mathrm{N}$ that are needed by coffee to sustain high yields. Since since total $\mathrm{N}$ is not a reliable indicator of $\mathrm{N}$ availability, $\mathrm{N}$ management practices should be based on expected yields and site-specific empirical assessments between fertilizer $\mathrm{N}$ application and economic crop response. Research in Puerto Rico has shown that yields of about $1,500 \mathrm{~kg} / \mathrm{ha}$ of coffee can be obtained with $200 \mathrm{~kg} \mathrm{~N} / \mathrm{ha} / \mathrm{yr}$ in years of good rainfall, and application of $300 \mathrm{~kg}$ $\mathrm{N} / \mathrm{ha} / \mathrm{yr}$ can maintain production of 3,000 $\mathrm{kg} \mathrm{ha}{ }^{-1}$ year of coffee (Abruña et al., 1959; Abruña et al., 1965; VicenteChandler et al., 1968). These fertilizer $\mathrm{N}$ recommendations need to be evaluated based on current $\mathrm{N}$ fertilizer prices and on-farm bean selling price.

Soil fertility depends on many factors, among them the soil OM, because it contributes to an increase in soil CEC which can serve to retain and increase the reserve of soil cations, improves soil structure physics and soil water relations (Torres et al., 2006). Soils with higher OM content are associated with increased population and diversity of microorganisms (Brechelt, 2008). A practice that is beneficial to increase levels of soil OM is the management of shade trees by pruning. Although some shade trees provide additional income by harvesting fruit, $\mathrm{N}$-fixing species are those that will be most beneficial for increasing soil OM (Marques et al., 2003). The selection of the shade tree and the management of it are important factors to consider in the establishment of sustainable coffee production of high yields. Montenegro (2005) reported that the association of inga (Inga vera) and poppy (Erythina poeppigiana) are very favorable for nitrogen fixation in the coffee. The application of compost and planting of vegetatative cover are other alternatives to improve the supply of OM. Although Perez et al. (2008), highlights the difficulty of balancing a program based solely on organic amendments because the inability to match crop uptake to nutrient supply. Organic amendments have other positive soil functions such as improving nutrient use efficiency and in improving water availability Marques et al. (2003).

\section{CONCLUSIONS}

Duicela (2002) has shown that knowledge of the soil physical and chemical characteristics under coffee production can be used to identify potential production areas, facilitates the interpretation of the nutritional status of the crop and can be used to make specific recommendations about nutrition 
management of coffee. We determined a minimum set of soil variables that are used as indicators of soil fertility. The minimum set of indicators represent those that should be taken into account in management plans coffee nutrition. A PCA permited the selection of variables and the grouping of locations into five class coffee soil to facilitate differentiated from managing crop nutrition. This allowed for making broad infererences as to the potential soil fertility problems as well as general recommendations. This process contributes to the sustainability of the coffee industry in the province of Barahona and improving the productivity of coffee farms.

\section{ACKNOWLEDGMENTS}

We acknowledge the technical staff of the Dominican Coffee Council (Barahona, Pedernales, Bahoruco and Independence), the Spanish International Cooperation Agency for financing the study through project PROTESUR, Also, a staff of IDIAF-PROTESUR with a presence in Palo Alto Experimental Station South Center IDIAF for your contributions.

\section{REFERENCES}

Abruña, F., Vicente-Chandler, J., Silva, S. 1959. The effects of different fertility levels on yields of intensively managed coffee in Puerto Rico. J. Agric. Univ. P.R. 43, 141146.

Abruña, F., Vicente-Chandler, J., Becerra, L.A., Bosque-Lugo R. 1965. Effects of liming and fertilization on yields and foliar composition of high-yielding sun-grown coffee in Puerto Rico. J. Agric. Univ. P.R. 49, 413428.
Almonte, I. 2008. Caracterización físico químicas de los suelos de las principales zonas cafetaleras de la República Dominicana. Instituto Dominicano de Investigaciones Agropecuarias y Forestales IDIAF y Consejo Dominicano del café. Foro Caf., 4 (1). Abril - septiembre 2008. Santo Domingo, República Dominicana. 42 p.

Almonte, I., Batista, I., Jiménez, H., Céspedes, C., Escarramán, A., Núñez, P. 2010. Efectos de la fertilización química sobre el rendimiento y la calidad del café. Foro caf. 6, 29-32.

Avelino, J., Perriot, J., Guyot, B., Pineda, C., Decazy, F., Cilas, C. 2002. Identifying terroir coffees in Honduras. Plantations, Recherche, Developpement. pp: 6-16.

Brechelt, A. 2008. Importancia de la materia orgánica en los suelos. Fundación Agricultura y Medio Ambiente (FAMA). Available online in: http://www.rapal.org/articulos files/organica.pdf

CODOCAFE. 2001. Consejo Dominicano del Café. Censo Nacional Cafetalero. República Dominicana.

CODOCAFE. 2002. Boletín estadístico Consejo Dominicano del Café (CODOCAFE). No. V. Santo Domingo, República Dominicana.

CODOCAFE. 2010. Consejo Dominicano del Café. Evolución reciente de la caficultura dominicana. Foro Caf. 6, 15 p.

CENICAFE. 1999. Fertilización. Almacigo. CENICAFE (Centro Nacional de Investigaciones del Café). Available online in: http://www.cenicafe.org

Duicela, L. 2002. Caracterización Edafológica de las Zonas de Producción de Café arábico, Ecuador.

Escarramán, A., Romero, J.M., Almonte, I., Ribeyre, F. Aguilar, P., Jimenez, H., Causse, A., Olivares, F., Ceballos, F. 2008. Atributos de la calidad del café en zonas productoras de la República Dominicana. Instituto Dominicano de Investigaciones Agropecuarias y Forestales (IDIAF) y Consejo Dominicano del Café (DODOCAFE), Santo Domingo, DO. 92 p.

Hergoualc'h, K., Skiba, U., Harmand, J., Henault, C. 2008. Fluxes of greenhouse gases from andosols under cofee monoculture or shaed by Inga densiflora in Costa Rica. Bioeochemistry 89, 329-345. 
InfoStat. 2008. Manual del usuario. Grupo InfoStat, FCA, versión 2004. Universidad Nacional de Córdoba. Editorial Brujas, Argentina.

Indeángelo, N., Wilson, M.G., Tasi, H.A.A. 2007. Indicadores de calidad para dos suelos con características vérticas de Entre Ríos (Argentina). Cad. Lab. Xeol. Laxe. Cor. 32, 111-125.

Marques, M.S., Sá, N.M., Scott, M.R. 2003. Descomposición, dinámica de los elementos inorgánicos y colonización por microrganismos de hojas de araribá (Centrolobium tomentosum Guill. ex Benth) en latosoles del bosque Atlántico brasileño. Agric. Téc. 63, 59 - 68.

Martínez, N. 2010. Diagnóstico de la fertilidad de los suelos cafetaleros y recomendaciones de manejo en la provincia Barahona. Tesis para optar por el título de: Maestría en Ecología y Medio Ambiente. Universidad Nacional Pedro Henríquez Ureña. Asesor Pedro Núñez y co asesores Ángel Pimentel e Isidro Almonte. República Dominicana, Santo Domingo. 127 p.

Montenegro, G.E.J. 2005. Efecto del aporte de nutrientes de la biomasa de tres tipos de árboles de sombra en sistemas de manejo de café orgánico y convencional. Tesis Mag. Sc. CATIE, Turrialba, Costa Rica. 67 p.

Montico, S. 2006. Manejo de situaciones con suelos salinos y alcalinos. Cátedra Manejo de Tierras, Facultad de Ciencias Agrarias, U.N. de Rosario. En línea http://www.produccionanimal.com.ar/suelos ganaderos/54-salinos $y$ alcalinos.pdf
Núñez, P., Cuevas, B. 2004. Especies arbóreas de valor comercial y cultivos alimenticios presentes en cafetales de las provincias Monseñor Novel y La Vega. Agroforestería. Res. Invest. Idiaf. 1, 1-27.

Page, A.L., Miller, R.H., Keeney, D.R. (Eds). 1982. Method of Soil Analysis, Part 2, Chemical and Microbiological Properties. Second Edition. American Society of Agronomy, Soil Science. Society of America, Madison.

Pérez, A. 2002. Validación de la Efectividad y Eficiencia de la Repela, Pepena y Graniteo en el Control de la Broca (Hypothenemus hampei Ferrari). Instituto Dominicano de Investigaciones Agropecuarias y Forestales (IDIAF), Barahona, República Dominicana.

Pérez, A. Cespedes, C., Núñez, P. 2008. Caracterización física-química y biológica de enmiendas orgánicas aplicadas en la producción de cultivos en República Dominicana. R.C. Suelo Nutr. Veg. 8, 10-29.

Torres, D., Rodríguez, N., Yendis, H., Florentino A., Zamora, F. 2006. Cambios en algunas propiedades químicas del suelo según el uso de la tierra en el sector el cebollal, Estado Falcón, Venezuela. Bioagro 18, 123-128.

Vicente-Chandler, J., Abruña, F., Bosque Lugo, R. and Silva, S. 1968. Intensive coffee culture in Puerto Rico. Boletín \#211. Universidad de Puerto Rico, Mayagüez, Estación Experimental Agrícola. $4 \mathrm{p}$. 